\title{
EXAMINATION OF THE SHARE OF MEDIUM AND HEAVY TRUCKS IN THE SR
}

\begin{abstract}
The state of the environment is deteriorating due to human activity. Today, almost no major international forum can avoid addressing environmental issues. Environmental protection has therefore become a mandatory issue for every responsible politician. In addition to contributing to economic growth, the role of road transport should be to ensure sustainable transport and solutions for people and goods around the world. The European Parliament has adopted Directive 2019/1161 on the promotion of environmentally friendly and energy-efficient road transport vehicles, which defines the obligations and forms of support for the procurement of environmentally friendly vehicles. In addition to these transport tasks, there is also a challenge to reduce $\mathrm{CO}_{2}$ emissions in transport through the use of new technologies in transport. Also in road freight transport, there are currently vehicles that use alternative fuels with a more favorable environmental impact. In connection with the current EU legislation, which aims to increase the share of these vehicles, attention is paid to the contribution of this area, analysis and examination of the current situation with trucks with alternative propulsion.
\end{abstract}

Keywords: road freight transport, alternative fuels, directive EU, environment.

\author{
Marek Dočkalik ${ }^{1}$ \\ ${ }^{1}$ Department of Road and Urban Transport, Faculty of Operation and Economics of Transport and \\ Communications, University of Žilina, Univerzitná 8215/1, 01026 Žilina; +421908456 636, \\ marek.dockalik@stud.uniza.sk
}

\section{Introduction}

The European Union is striving to achieve a sustainable, competitive, secure and decarbonized energy system. The European Union has set ambitious commitments to further reduce greenhouse gas emissions by at least $40 \%$ by 2030 compared to 1990 levels, increase the share of renewable energy consumption by at least $27 \%$, and increase energy security, competitiveness and sustainability in the Union. The decarbonization of the transport sector must be accelerated and it will therefore be necessary to steadily reduce greenhouse gas and air pollutant emissions from transport in order to reach zero levels by the middle of the century. In addition, there is an urgent need to significantly reduce transport emissions of air pollutants that are harmful to health and the environment (EU Directive 2019/1161).

Innovations in new technologies help reduce $\mathrm{CO}_{2}$ emissions from vehicles and reduce air pollution and noise pollution, while supporting the decarbonization of the transport sector. Increased use of low- and zero-emission road vehicles will reduce $\mathrm{CO}_{2}$ emissions as well as certain pollutants (particulate matter, nitrogen oxides and hydrocarbons other than methane) and thus improve air quality in cities and other polluted areas (EU Directive 2019/1161).

The availability of sufficient charging and pumping infrastructure is also essential for the introduction of alternative fuel vehicles. The European Parliament has called on Member States to promote green public procurement policies through the purchase of zeroemission and very low-emission vehicles by public authorities for their own fleets or through public or mixed vehicle-sharing schemes, and to phase out new vehicles by 2035 vehicles emitting $\mathrm{CO}_{2}$ emissions (EU Directive 2019/1161).

The use of ecological vehicles in road freight transport to a greater extent can help to meet the EU objectives, therefore the paper focuses mainly on examining the current share of ecological vehicles in road freight transport in the Slovak Republic and abroad.

\section{Application of EU Directive 2019/1161 on the promotion of clean and energy efficient road transport vehicles}

The EU requires Member States, through the transposition of EU Directive 2019/1161, to ensure that contracting authorities and contracting entities take into account energy and environmental impacts during the lifetime of a vehicle when procuring certain road transport vehicles, including energy consumption and $\mathrm{CO}_{2}$ emissions and certain pollutants, in order to promote and stimulate the market for clean and energy efficient vehicles and improve the contribution of the transport sector to the Union's environment, climate and energy policies.

EU Directive 2019/1161 states for each EU Member State what the minimum percentages of clean vehicles in the total number of road transport vehicles should be included in the sum of all contracts subject to that EU directive.

It is the responsibility of EU Member States to ensure that the required minimum procurement targets for clean vehicles are met when procuring vehicles and services falling within the scope of EU Directive 2019/1161. These percentages are given separately for each EU Member State and depending on the reference period. These are two reference periods, the first being the period from 2 August 2021 to 31 December 2025. The second reference period is the period from 1 January 2026 to 31 December 2030.

In some EU Member States, compared to the Slovak Republic, the required procurement targets are higher for the share of environmentally friendly vehicles in the N1, N2, N3 vehicle category. In Fig. 1 sets out the minimum required values under EU Directive 2019/1161 for each Member State. Figure 1 also shows data for the United 
Kingdom. It is clear from the data that higher percentages of clean vehicles will be required especially in the countries of Western and Northern Europe or in the countries that are part of the so-called EU-15, as these countries already make much more use of alternative propulsion vehicles or vehicles that meet the conditions of the definition of an environmentally friendly vehicle. In the category of $\mathrm{N} 2$ and $\mathrm{N} 3$ trucks, these shares are in most cases at $10 \%$ in the first reference period and in most cases the required value is $15 \%$.

Conversely, for some countries, lower minimum procurement targets are set for the share of clean vehicles. These are in particular the Baltic States, the V4 States and the Balkans and South-Eastern Europe. According to EU Directive 2019/1161, the stated required values are only minimal, and each state can commit to higher values through its own legislation. The Slovak Republic is also among the countries where the required target value for the procurement of ecological vehicles is lower compared to the countries of Western and Northern Europe. As the United Kingdom was until recently an EU Member State, the minimum procurement targets for the share of clean vehicles were also set, and the same as for most Western European countries.

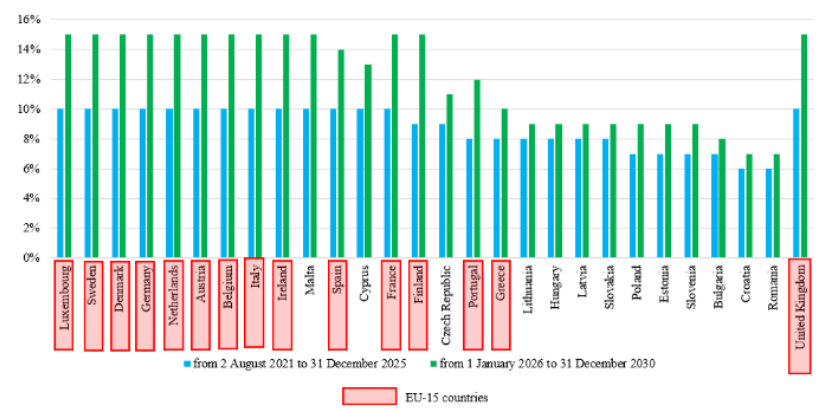

Fig. 1 The absolute and relative number of trucks with alt. fuel in the SR (Source: author based on Directive EU 2019/1161)

The aim is to increase the share of clean vehicles in road freight transport also through this legislation.

\section{Truck fleet analysis in Europe}

Alternative fuels are gradually being used in road freight transport in the EU. In the N1 truck category, electricity or liquefied petroleum gas may be an available alternative to conventional propulsion. In the category of $\mathrm{N} 2$ and N3 trucks, currently the most used vehicles with alternative types of $\mathrm{CNG}$ or LNG propulsion are.

Vehicles in this category (N2 and N3) powered by hydrogen or electricity are also becoming available to carriers. But at present there are very few of these vehicles, e.g. in Europe, the first 10 hydrogen fuel cell-powered Huyndai XCIENT Fuel Cell trucks are already driving. They are used by customers in Switzerland, where tax incentives for hydrogen vehicles and a good hydrogen infrastructure create the space for this new technology to be put into practice (Transport 2020). Due to the low number of other vehicles in the N2 and N3 category with alternative propulsion, only $\mathrm{CNG} / \mathrm{LNG}$ vehicles predominate in the statistics on trucks using alternative fuels.

Truck manufacturers offer these alternative propulsion vehicles (CNG / LNG) to their customers, and some customers have requirements for carriers to use these vehicles. At present, the construction of the vehicle is of great importance, especially its ecological operation, respectively reducing the ecological burden on the environment.

Manufacturers of LNG trucks, namely Scania, Volvo and Iveco, state that operating LNG trucks can reduce $\mathrm{CO}_{2}$ emissions by $15 \%$ to $20 \%$ compared to Euro VI, up to $95 \%$ if biogas is used, $95 \%$ less solids, $25 \%$ to $70 \%$ less nitrous oxide and, of course, a significant reduction in noise pollution. The percentage reduction in emissions is declared by the manufacturers for in-service car emissions, known as "tank-to-wheel" (Iveco 2020, Volvo trucks 2020, Hagos et al. 2018).

According to Danish transport research, in which the authors looked at the prospects for gas in transport in Denmark, using LNG can reduce greenhouse gas emissions by at least $15 \%$ per $\mathrm{km}$ if it is a well-to-wheel expression, a comprehensive expression taking into account greenhouse gas emissions, gases from the extraction of the raw material to its final consumption. By using renewable components, this effect can be several times higher (Hagos et al. 2018).

A study by the Oxford Institute for Energy Studies (2014) sees the greatest potential for natural gas in transport in heavy goods transport. It notes that, compared to heavy goods vehicles and diesel buses, emissions taking into account other greenhouse gases in terms of $\mathrm{CO}_{2 \mathrm{e}}$ (carbon dioxide equivalent) per $\mathrm{km}$ by 2030 may be $15 \%$ lower in a well-to-wheel mode. This is confirmed by a recent study by the Oxford Institute for Energy Studies from 2019. $\mathrm{CO}_{2 \mathrm{e}}$ emissions can be even lower when using bio-LNG. Values are given in $\mathrm{g} \mathrm{CO}_{2 \mathrm{e}} / \mathrm{km}$ (Oxfordenergy 2019).

Table 1. Well-to-wheel $\mathrm{CO}_{2 \mathrm{e}} \mathrm{g} / \mathrm{km} \mathrm{LNG} \mathrm{truck}$ (Source: Oxfordenergy 2019)

\begin{tabular}{|c|c|c|c|c|c|}
\hline $\begin{array}{c}\text { Heavy } \\
\text { Trucks }\end{array}$ & Diesel & CNG & LNG & $\begin{array}{c}80 \% \text { CNG } \\
+20 \% \text { bio }\end{array}$ & $\begin{array}{c}80 \% \text { LNG } \\
+20 \% \text { bio }\end{array}$ \\
\hline $\mathrm{CO}_{2 \mathrm{e}}[\mathrm{g} / \mathrm{km}]$ & 1,074 & 908 & 912 & 738 & 749 \\
\hline
\end{tabular}

The number of trucks over 3.5 tonnes is increasing every year in the EU. Importantly, the number of road freight vehicles using alternative $\mathrm{CNG}$ or LNG fuels is also gradually increasing, and this trend has been due to support from the EU or individual Member States. The ACEA report, January 2021, provides a comprehensive overview of the European vehicle fleet. For each country, it shows the number of vehicles used in each segment - including passenger cars, light commercial vehicles, medium and heavy commercial vehicles and buses and the development of this vehicle fleet in recent years, including a breakdown by type of fuel used.

Diesel-powered light commercial vehicles are dominant in all EU countries. Almost $90 \%$ of the EU's light commercial vehicle fleet ride on diesel, $7.8 \%$ use petrol as fuel and only $0.3 \%$ of light commercial vehicles in the EU 
use electricity (ACEA Vehicles in use Europe January 2021).

At present, as many as $97.8 \%$ of all medium and heavy trucks in the EU still use diesel, while petrol uses $1.3 \%$ of the EU truck fleet. The number of medium and heavy-duty trucks using alternative fuels is still minimal, as diesel is the dominant type of fuel. This is understandable given the technologies available, the infrastructure and the impact of procuring an alternative vehicle on the transport company's costs. Overall, $0.4 \%$ of trucks in the EU use natural fuel and natural gas use liquefied petroleum gas (ACEA Vehicles in use Europe January 2021).

An overview of the number of medium and heavy commercial vehicles is given in absolute terms in the following table without data for the United Kingdom.

Table 2. An overview of the number of medium and heavy trucks in the EU (Source: ACEA Vehicles in use Europe January 2021, ACEA Vehicles in use Europe 2019, ACEA Vehicles in use Europe 2018)

\begin{tabular}{|c|c|c|c|c|c|c|}
\hline Year & 2014 & 2015 & 2016 & 2017 & 2018 & 2019 \\
\hline $\begin{array}{c}\text { Total number } \\
\text { of vehicles }\end{array}$ & $5,533,777$ & $5,765,018$ & $5,881,445$ & $6,020,307$ & $6,143,333$ & $6,229,282$ \\
\hline
\end{tabular}

An overview of the number of medium and heavy commercial vehicles with alternative fuel types LNG and $\mathrm{CNG}$ is given in absolute numbers in the following table without data for the United Kingdom.

Table 3. An overview of the number of LNG and CNG medium and heavy trucks in the EU (Source: ACEA Vehicles in use Europe January 2021, ACEA Vehicles in use Europe 2019, ACEA Vehicles in use Europe 2018)

\begin{tabular}{|c|c|c|c|}
\hline Year & 2017 & 2018 & 2019 \\
\hline CNG/LNG vehicles & 24,081 & 24,573 & 24,917 \\
\hline
\end{tabular}

\section{GDP growth}

The procurement of new N2, N3 trucks with alternative propulsion is certainly essential and important in meeting the EU's emission reduction commitments. The decision to buy this type of vehicle may depend on several factors. The awareness of human society about the need to look for ecological methods in transport, the level of development of countries and, to a large extent, the political strategies and directions of individual states, but also from the size of GDP, certainly contributes to this. Therefore, data have been calculated and reported between the gross domestic product of each region of Europe per capita in 2019 and the percentage of trucks with alternative propulsion in these areas, which show that the higher the GDP, the more registered the freight vehicles with alternative propulsion.
Table 4. GDP/cap. and trucks in selected areas of the EU (Source: ACEA Vehicles in use Europe January 2021, 12. Eurostat. GDP and main components (output, expenditure and income))

\begin{tabular}{|l|c|c|c|}
\hline & V4 & EU-15 countries & Nordic countries \\
\hline GDP/cap. [€] & 15,603 & 36,520 & 51,021 \\
\hline Trucks with alt. fuel [\%] & 0.13 & 0.39 & 0.63 \\
\hline
\end{tabular}

\section{Trucks in the SR by type of propulsion}

In the Slovak Republic, carriers are also starting to procure trucks with an alternative type of drive. This fact can be influenced by a number of factors, e.g. striving to be more environmentally friendly, possible cost reduction and savings, customer pressure to procure these vehicles, legislation, etc. From the available data obtained from the Police Force of the SR (Police Force of the SR), the following table analyses by region the vehicle fleet of the SR. The analysis is focused on trucks of categories N2 and N3 in the Slovak Republic and obtaining data on the number of vehicles with an alternative type of fuel, which can be considered an ecological vehicle according to EU Directive 2019/1161.

Table 5. Vehicles of categories N2 and N3 by region (Source: Police Force of the Slovak Republic, STATdat.)

\begin{tabular}{|l|c|c|c|c|c|c|c|c|c|}
\hline & SR & BA & TT & TN & NR & ZA & BB & PO & KE \\
\hline Total & 79,685 & 14,738 & 9,428 & 8,017 & 11,335 & 9,701 & 9,110 & 8,836 & 8,520 \\
\hline CNG & 40 & 7 & 2 & 12 & 3 & 7 & 4 & 4 & 1 \\
\hline LNG & 85 & 45 & 6 & 3 & 1 & 0 & 9 & 1 & 20 \\
\hline LPG & 14 & 0 & 0 & 2 & 0 & 0 & 9 & 3 & 0 \\
\hline Electricity & 2 & 0 & 0 & 0 & 1 & 1 & 0 & 0 & 0 \\
\hline Petrol & 109 & 28 & 13 & 18 & 4 & 19 & 12 & 7 & 8 \\
\hline Diesel & 79,435 & 14,658 & 9,407 & 7,982 & 11,326 & 9,674 & 9,076 & 8,821 & 8,491 \\
\hline $\begin{array}{l}\text { Vehicles } \\
\text { with alt. fuel }\end{array}$ & 141 & 52 & 8 & 17 & 5 & 8 & 22 & 8 & 21 \\
\hline $\begin{array}{l}\text { The } \\
\text { population }\end{array}$ & $5,459,781$ & $6735 \%$ & $0.08 \%$ & $0.21 \%$ & $0.04 \%$ & $0.08 \%$ & $0.24 \%$ & $0.09 \%$ & $0.25 \%$ \\
\hline $\begin{array}{l}\text { Vehicles } \\
\text { with alt. fuel } \\
100,000 \\
\text { inhabitants }\end{array}$ & 2.58 & 765,324 & 582,567 & 671,508 & 691,136 & 643,102 & 827,028 & 802,092 \\
\hline
\end{tabular}

From the available analysed data, it can be seen that in the Slovak Republic there are currently 141 trucks of categories $\mathrm{N} 2$ and $\mathrm{N} 3$, which use an alternative fuel, liquefied or compressed natural gas, or liquefied petroleum gas as their source of propulsion. With a total of 79,685 vehicles, the number of vehicles in this category is $0.18 \%$ in relative terms. Compared to the EU average, this number is lower in the Slovak Republic, as in the EU on average $0.6 \%$ of medium and heavy trucks using alternative fuel are natural or oil gas.

Looking at the more detailed statistics by region, it is visible that the highest number of trucks of category N2 and N3 with an alternative type of drive within the distribution by region of the Slovak Republic is in the Bratislava region. There are 52 trucks with an alternative type of drive registered in this region. Even in relative terms, there is the highest share of ecological trucks, namely $0.35 \%$, which is almost twice the average of Slovakia $0.18 \%$. The Košice, Banská Bystrica and Trenčín regions are also at approximately the same level $(21,22$ and 17 cars). The lowest number of ecological trucks is in Prešov, Trnava, Žilina (8 vehicles) and the Nitra region (5 vehicles). With the decreasing number of vehicles with alternative propulsion in absolute terms, the decrease in 
ecological vehicles in relative terms is also visible. In addition to the Bratislava region, the share of ecological vehicles in the Košice, Banská Bystrica and Trenčín regions is above the Slovak average. These data are also graphically expressed in Figure 2.

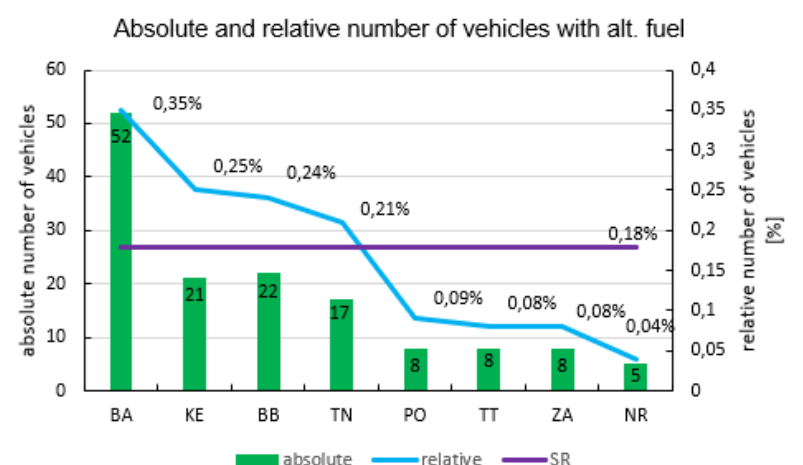

Fig. 2 The absolute and relative number of trucks with alt. fuel in the SR (Source: author)

The number of ecological trucks in individual regions per 100,000 inhabitants was also examined. Also in this statement, there are significantly the most environmentally friendly trucks in the Bratislava region, namely 7.68 vehicles/100,000 inhabitants. The national average represents a value of 2.58 vehicles/100,000 inhabitants. The Banská Bystrica, Trenčín and Košice regions are still higher than the average for the whole of Slovakia. The data show that from every part of the Slovak Republic (west, middle, east) there is at least one region with the number of ecological vehicles per 100,000 inhabitants. above the SR average. On the contrary, below this average value are again the regions Trnavský, Žilinský, Prešovský and the least ecological trucks per 100,000 inhabitants is in the Nitra region (Fig. 3).

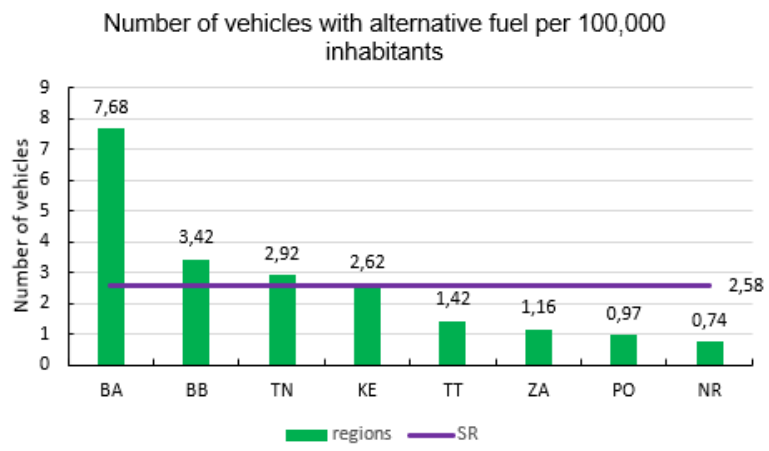

Fig. 3 Number of vehicles with alternative fuel per 100,000 inhabitants. (Source: author)

The decision to buy an eco-friendly truck can be influenced by several factors. The situation and development of the economy in individual areas can also be one of them. The relationship between the number of clean trucks and the GDP of each region was therefore examined. As GDP grows, so does the transport performance of road freight transport and thus the need to procure new trucks (Gnap et al. 2018). An analysis of the European V4 regions, the EU-15 and the Nordic countries shows that the higher the GDP, the higher the number of vehicles using alternative fuels. GDP was converted per capita for each region. Data on the population of individual regions and the level of GDP were obtained from sources (STATdat.). A similar course can be seen in a certain part of the examined sample of Slovak regions. The highest GDP is the highest in the Bratislava region and also in this region there are the most registered ecological trucks. Compared to the Bratislava region, GDP is lower in the remaining regions, between which there are no significant differences in terms of per capita. There is also a comparable number of ecological trucks in the Košice, Banská Bystrica and Trenčín regions. In the remaining regions (Prešov, Trnava, Žilina, Nitra), the number of ecological trucks is much lower, despite the comparable level of GDP with the Košice, Banská Bystrica and Trenčín regions.

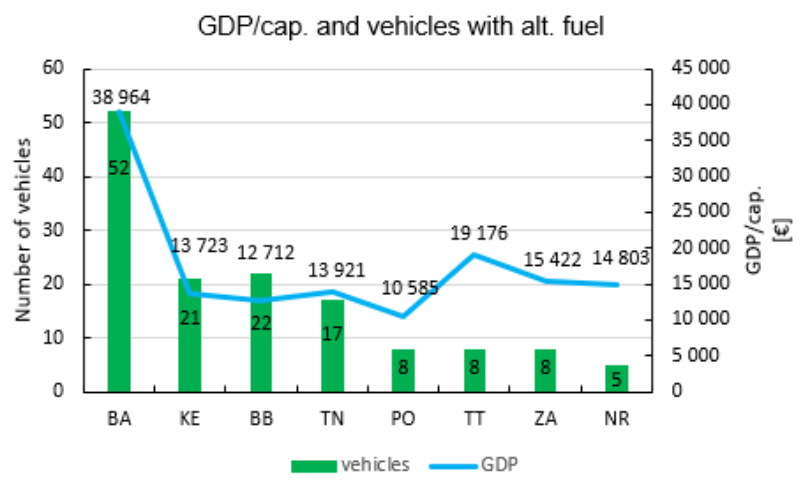

Fig. 4 GDP/cap. and vehicles with alt. fuel (Source: author)

\section{Conclusion}

The EU's ambitious goals of reducing greenhouse gases, producing $\mathrm{CO}_{2}$, increasing the share of energy from renewable sources, making greater use of alternative energy sources and, in order to achieve these goals, it is important to pay close attention to the tools that can ultimately lead to them. One option is to create policy initiatives that can put positive pressure on the procurement of more environmentally friendly road transport vehicles. Gradually, vehicles with alternative modes of propulsion are also being used in road passenger or freight transport, and further measures may lead to this trend in a positive direction.

Public procurement can influence and strengthen the market for green vehicles. As public expenditure on goods, works and services accounted for $16 \%$ of GDP in the EU in 2018, the EU decided to adopt Directive 2019/1161, which sets minimum requirements for clean vehicles for Member States when procuring vehicles or providing specific services. The use of this tool is also expected to increase the use of vehicles with alternative fuels in road freight transport, as in this area the market is currently absolutely dominated by vehicles with conventional propulsion, which can be claimed based on analysed data for the EU and Slovakia.

European countries with a higher share of GDP per capita also have a higher share of green truck registrations. 
How this area will be affected in the context of the COVID - 19 pandemic will need to be thoroughly investigated at the end of this period.

There are not many alternative solutions available for road freight transport in the $\mathrm{N} 2$ and $\mathrm{N} 3$ vehicle categories. The use of CNG or LNG in heavy goods vehicles certainly represents a contribution to $\mathrm{CO}_{2}$ reduction in the transport sector. In a study (Smajla et al. 2019), data were tested on 18 trucks for LNG over 15 months, and the authors concluded that LNG as a fuel reduced costs and harmful emissions. Similar fuel consumption based on equivalent energy was achieved for liquefied natural gas trucks during the study period. On average, fuel costs for LNG trucks were about $48 \%$ lower than for diesel trucks. With such cost estimates, the payback period is less than three years (Smajla et al. 2019).

The EU's ambitious targets for reducing $\mathrm{CO}_{2}$ emissions from transport can benefit the environment and human society in the future. The aim of the paper was to find out the current state of the vehicle fleet in the EU and in the Slovak Republic. The number of trucks that use alternative fuels in absolute, relative terms and per 100,000 inhabitants is also examined. The relationship between the number of ecological vehicles and GDP per capita is also examined. The survey focused on vehicle categories N2, $\mathrm{N} 3$ and areas were divided by region.

\section{References}

ACEA. Vehicles in use Europe January 2021 [online]. Available from:

https://www.acea.auto/uploads/publications/reportvehicles-in-use-europe-january2021.pdf? fbclid=IwAR2rq17XQPGbJ7DgWZwlppB nuQlrJCkeFgvGPrS17Z5vVwSKdq0Icd9gUOo.

ACEA. Vehicles in use Europe 2019 [online]. Available from:

https://www.acea.auto/uploads/publications/ACEA_ Report_Vehicles_in_use-Europe_2019.pdf.

ACEA. Vehicles in use Europe 2018 [online]. Available from:

https://www.acea.auto/files/ACEA_Report_Vehicles in_use-Europe_2018.pdf.

Eurostat. GDP and main components (output, expenditure and income), [online]. Available from: https://appsso.eurostat.ec.europa.eu/nui/show.do?dat aset=nama_10_gdp\&lang=en.

Gnap, J., Konečný, V., Varjan, P. 2018 Research on relationship between freight transport performance and GDP in Slovakia and EU countries. NAŠE MORE: znanstveni časopis za more I pomorstvo, 65(1), 32-39.

Hagos, D. A., Ahlgren, E. O. 2018 Well-to-wheel assessment of natural gas vehicles and their fuel supply infrastructures-Perspectives on gas in transport in Denmark. Transportation Research Part D: Transport and Environment, 65, 14-35.

Iveco. 2020 [online]. Available from: https://www.iveco.com/slovakia/produkty/pages/stra lis_natural_power.aspx.
Oxfordenergy. 2019 [online]. Available from: https://www.oxfordenergy.org/wpcms/wpcontent/uploads/2019/04/A-review-of-prospects-fornatural-gas-as-a-fuel-in-road-transport-Insight50.pdf.

Slovak Police Force. Central vehicle register of the Slovak Republic.

Scania. Available from: https://www.scania.com/sk/sk/home/experiencescania/news-and-events/News /archive/2019/05/spolo_nos_-bosta-smeruje-k-udratenej-preprave-vaka-vozidlam-sca.html.

Smajla, I. et al. 2019 Fuel switch to LNG in heavy truck traffic. Energies, 12(3).

Directive (EU) 2019/1161 of the European Parliament and of the Council of 20 June 2019 amending Directive 2009/33/EC on the promotion of clean and energyefficient road transport vehicles.

STATdat. Population by sex - SR, areas, counties, districts, city, countryside (annually). [online]. Available from: http://statdat.statistics.sk/cognosext/cgibin/cognos.cgi?b_action=cognosViewer\&ui.action $=r$ un\&ui.object=storeID $\% 28 \% 22 \mathrm{i} 362 \mathrm{DCE} 4 \mathrm{D} 88 \mathrm{EC} 4 \mathrm{E}$ 13A9EE8526B286D18B $\% 22 \% 29 \&$ ui.name $=\mathrm{Po} \% \mathrm{C} 4$ $\% 8$ Det $\% 20$ obyvate $\%$ C4\%BEov $\% 20$ pod $\% \mathrm{C} 4 \% \mathrm{BEa}$ $\% 20$ pohlavia $\% 20$ $\% 20$ SR $\% 2 \mathrm{C} \% 20$ oblasti $\% 2 \mathrm{C} \% 20 \mathrm{kraje} \% 2 \mathrm{C} \% 20$ okre sy $\% 2 \mathrm{C} \% 20$ mesto $\% 2 \mathrm{C} \% 20$ vidiek $\% 20 \% 28$ ro $\% \mathrm{C} 4 \%$ 8Dne\%29\%20\%5Bom7102rr\%5D\&run.outputForm at $=\&$ run.prompt $=$ true \&cv.header $=$ false \&ui.backUR $\mathrm{L}=\% 2 \mathrm{~F}$ cognosext $\% 2 \mathrm{Fcps} 4 \% 2 \mathrm{Fportlets} \% 2 \mathrm{Fcommon}$ $\% 2$ Fclose.html\&run.outputLocale $=$ sk.

STATdat. Revised and preliminary annual GDP data at current prices. [online]. Available from: http://statdat.statistics.sk/cognosext/cgi-

bin/cognos.cgi?b_action $=$ cognosViewer\&ui.action $=r$ un\&ui.object $=$ storeID(\%22i610B437944574D7E851 0F69AEBE735A7\%22)\&ui.name=Revidovan $\%$ c3\% a9\%20a\%20predbe \%c5\%ben \%c3\%a9\%20ro \%c4\%8 $\mathrm{dn} \%$ c3\%a9\%20\%c3\%badaje $\% 20 \mathrm{HDP} \% 20 \mathrm{v} \% 20$ be $\%$ c5\%ben $\%$ c3\%bdch $\% 20$ cen $\%$ c3\%alch $\% 20 \% 5$ bnu $0007 \mathrm{rs} \% 5 \mathrm{~d} \&$ run.outputFormat $=\&$ run.prompt $=$ true $\&$ cv.header $=$ false \&ui.backURL $=\% 2$ fcognosext $\% 2 \mathrm{fcp}$ s4\%2fportlets $\% 2$ fcommon $\% 2$ fclose.html\&run.outpu tLocale $=$ sk.

Transport. 2020. [online]. Available from: https://ransport.sk/spravy/cestna-doprava/vosvajciarsku-zacali-vyuzivat-vodikove-nakladnevozidla/.

Volvo trucks. 2020. [online]. Available from: https://www.volvotrucks.sk/sk-sk/trucks/volvofh/volvo-fh-lng.html. 